\title{
Model of decision for the management of technology and risk in a port community
}

\author{
Claudia Durán $^{\mathrm{a}^{*}}$, Raúl Carrasco ${ }^{\mathrm{b}, \mathrm{c}}$ and Juan M. Sepúlveda ${ }^{\mathrm{a}}$ \\ ${ }^{a}$ Industrial Engineering Department, University of Santiago of Chile, Santiago, Chile \\ ${ }^{b}$ Faculty of Administration and Economics, University of Santiago of Chile, Santiago, Chile \\ ${ }^{c}$ Faculty of Engineering, Science and Technology, University Bernardo O'Higgins, Santiago, Chile

\section{H R O N I C L E}

\section{A B S T R A C T}

\begin{tabular}{l}
\hline Article history: \\
Received March 16, 2017 \\
Received in revised format: \\
August 20, 2017 \\
Accepted September 10, 2017 \\
Available online \\
September 10, 2017 \\
\hline Keywords: \\
ANP \\
System of components \\
Strategic management \\
Synergy relationship \\
Decision-making \\
\end{tabular}

\begin{abstract}
Strategic management in a port system is complex since the Port Community has to coordinate actions and generate synergy among all the private actors that integrate the export and import logistics chains, trade associations and trade unions. Based on the opinion of the port experts and the analytical network process (ANP), the research identifies the relevant criteria for strategic, business and operational decision-making in the Port Community, in the technological and risk contexts. With the criteria found and considering the strategic alignment that is required, management indicators are constructed. Based on a generic model, a new strategic conceptual model (PORTGD) of ANP for decision management is designed for the Port Community, a cause and effect analysis is carried out and a sensitization study is performed on the nodes. The discussion of the results and conclusions highlights the importance of technological investment, control of port security and good practices for the port system investigated.
\end{abstract}

(C) 2018 Growing Science Ltd. All rights reserved.

\section{Introduction}

Medium-sized Chilean ports are considered as systems that permanently interact with a technological and risk macro-environment; they are part of a complex network of private and public actors who are interrelated to provide cargo services for import and export operations (Durán \& Cordova, 2016). The port system is coordinated by the Port Community which is part of the business Core and, by port law, plays the role of governance. The PC is composed of private companies such as the Port Administrator and the internal and external port terminals, whose concession has been granted by the State of Chile. The PC permanently interacts with a PESTE macro-environment (political, economic, social, technological and environmental) and is responsible for the decision-making process related to the Port Strategic Management (Durán \& Cordova, 2016; Hao \& Song, 2016).

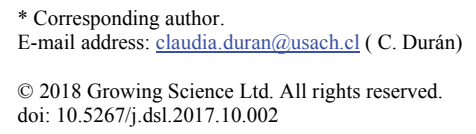


The decisions made by the companies that are the Core of the business are multiple and complex, they can increase or decrease the degree of synergy between the private and public actors of the port system and therefore affect: the competitiveness of the port and the integration / collaboration between the actors of the export and import logistics chains (Carlan et al., 2016; Wei, 2010; Zhong et al., 2011). Strategies are also relevant for defining the strategic/operational objectives of communication and technology processes, where multiple decisions are made to optimize the flow of information (Durán \& Córdova, 2015; Keceli, 2011) and improve the control of port activities (Van Oosterhout et al., 2007). The Port Community, for its role of coordinator of the system, is responsible for the decision-making process; it has to set varied objectives and choose the best possible alternatives to increase profitability. In order to do this, it is necessary to reduce the costs related to Information and Communication Technologies by means of implementing/safeguarding: the efficient use of stakeholders' infrastructure (Keceli, 2011), security of connections between users (Van Oosterhout et al., 2007), legality in transactions (Carlan et al., 2016), rapid access to information through electronic platforms (Aydogdu \& Aksoy, 2015), compliance with standards and regulations (Carlan et al., 2016), among others. At the same time, it has to manage the data of the Information and Technology Processes of the port terminals. So, there is a collaborative platform to make the handling of the great amount of information generated more effective (Durán \& Córdova, 2015).

Then, from the information implicit in the strategies and the processes of information management, it is possible to obtain strategic knowledge, which can be used as the basis for the decision-making over multiple criteria in an organization (Do Carmo et al., 2016; Wu \& Lee, 2007). In particular, it can be observed that each port actor has defined strategies containing information that can be classified accordingly with the multi-criteria of the macro environment PESTE (political, economic, social, technological and environmental), which together evidence the degrees of strategic synergy generated in the port system (Durán \& Cordova, 2016). There is a very complex synergic network in which each actor has to align his strategic decisions with his strategic and operational objectives (Montibeller \& Belton, 2006) and all of the actors in the port system should be aligned with the strategic decisions of the Port Community (Durán \& Córdova, 2015).

To solve problems about multiple decisions made in a network, the Analytical Network Process model (ANP) can be used, which is a generalization of the Analytical Hierarchical Processes model (AHP) ( Yang et al., 2013). The ANP model better analyzes the complexity of a system, since it provides all the interactions between the objectives and the control criteria; the networks of influence relations that are generated between the elements and groups of elements that are investigated (Yang et al., 2013).

In order to identify the criteria and relevant decisions that the Port Community has to undertake, the ANP will be used to investigate in depth the strategic, tactical and operational relationships in the contexts of technology and risk; that is, it is possible to explore the strategies and objectives of an organization by structuring a network including clusters, nodes, alternatives and their inner and outer dependencies (Wu \& Lee, 2007; Yang et al., 2013). With the ANP model, we can apply criteria to study the interaction and dependence between two elements, also the dependency structure of the model allows the analysis of the network and the degrees of dependence that exist in the relationships of pairs of elements that are investigated; it is possible to identify relationships and cause and effect maps (Montibeller \& Belton, 2006). Hsu (2011) and Wu \& Lee (2007) state that the ANP model has also been used: to study the management of green logistics chains in the evaluation of strategies (Cao et al., 2010), in alignment with and for developing performance evaluation indices based on Balanced Scorecard in knowledge management, among others (Wu \& Lee, 2007; Yang et al., 2013). Finally, it is emphasized that there is a lack of research related to the influence of risk and technology on decisions made in such a complex system as a public port granted in concession to private companies, using the ANP model.

The article is structured in the following way: it starts by providing a brief description of the actors who integrate the port system, then follows the design of a new ANP decision model for the Port Community 
based on strategic necessities of the port system, then follows the design of a new ANP decision model for the Port Community based on strategic needs of the port system, to continue with the application of the new ANP model; finally, the results are analysed, synergetic relationships are discussed and the conclusions of the investigation are proposed.

\section{Material and method}

\subsection{Description of port actors}

As shown in Fig. 1, the Port System is composed of: the Port Community comprising the Port Authority and the Externalized/Internal Terminals, private companies providing logistics services, Labor Unions and Trade Associations. Exist degrees of synergy, collaboration, coordination and transfer of economic/physical resources and information among the actors in the network of the port system. Each actor who participates in the port system makes individual decisions in order to support the activities that contribute to the fulfillment of the strategic and operational objectives defined by the Port Community.

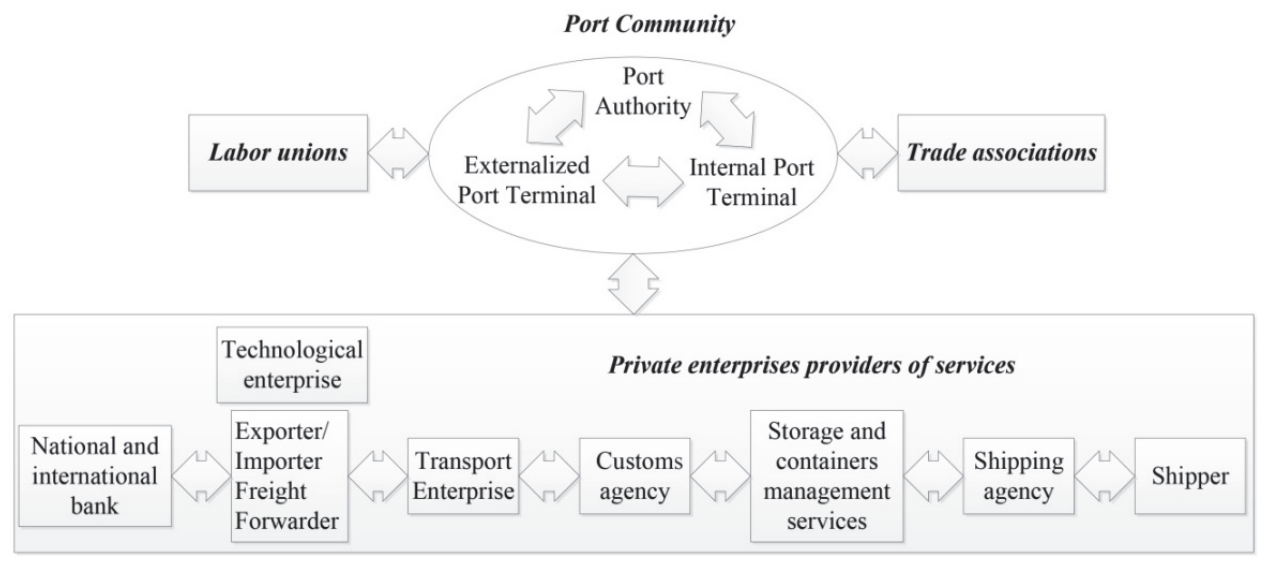

Fig. 1. Port private actors. Adapted (Durán \& Córdova, 2015)

\subsection{Identification of the current problem}

The various actors in the export and import logistics chains represent a big challenge, especially because of their cultural differences and diversity of interests, reflected in a lack of alignment of their objectives. Likewise, their relationships with the macro- and micro-environment are a source of permanent stimuli that generate stress in the system (Durán \& Cordova, 2016).

What directly affects the strategic planning of the Port Community is the interaction between the Port Authority, the Internal /Outsourced Terminals and the Labor Unions, since if they do not come to a labour agreement, activities can be paralyzed for short or long periods of time; this situation affects the competitiveness of the port and subjects it to significant levels of risk, which can be observed when the activities of the export and import logistics chains are paralyzed.

With regard to technology, it is observed that not all of the actors in the port system have the same technology or the same degree of integration with the other actors concerning the information and documentation processes. However, due to globalization, more and more actors must adopt new technologies and innovative practices for the information and communication processes, define strategies with the purpose of increasing service demands and achieving a more competitive port; in addition, more technology is needed to process a large amount of data generated by the management of the logistics chains, more collaborative platforms are needed to improve the planning and traceability of port activities. Another important factor to consider is the automation of control activities in terms 
of coordination and control of the flow of cargo at entry and exit areas from the port; technology can also be incorporated in the storage, consolidation, de-consolidation of containers. Automation permits greater profitability and increases port security at gates, in the yard cranes, in the quay cranes and in transportation.

In Table 1 the strategic phrases of all port actors and their roles have been displayed in order to identify those actors who express in their strategic purposes they are currently making strategic decisions related to the technological and risk criteria, according to the strategic role they have in the port system (Durán, Sepulveda, \& Carrasco, 2018; Sandhya \& Garg, 2016).

\section{Table 1}

Multi-criteria classification of the strategies of the port actors, in the technological and risk context. Based (Durán et al., 2018).

\begin{tabular}{|c|c|c|c|}
\hline Actor & $\begin{array}{l}\text { Role of the } \\
\text { actors }\end{array}$ & $\begin{array}{l}\text { Generic strategic phrases of a port system related to } \\
\text { the technological and risk aspects }\end{array}$ & $\begin{array}{l}\text { Multi-criteria } \\
\text { classification }\end{array}$ \\
\hline Port community & $\begin{array}{l}\text { Core of the } \\
\text { port business }\end{array}$ & $\begin{array}{l}\text { "Ensure the provision of port services to the logistics } \\
\text { chain and the customer, within a framework of a } \\
\text { permanent technological innovation that provides high } \\
\text { levels of quality of service" }\end{array}$ & $\begin{array}{l}\text { Technological and } \\
\text { risk }\end{array}$ \\
\hline $\begin{array}{l}\text { Exporter / importer / Freight } \\
\text { forwarder }\end{array}$ & Clients & $\begin{array}{l}\text { "To offer national and international clients high quality, } \\
\text { efficient and reliable commercial solutions for maritime } \\
\text { and terrestrial transport" }\end{array}$ & Risk \\
\hline Customs and shipping agency & $\begin{array}{l}\text { Strategic } \\
\text { partner }\end{array}$ & $\begin{array}{l}\text { "Provide customers with a comprehensive logistics port } \\
\text { service generating solutions of excellence and added } \\
\text { value" }\end{array}$ & $\begin{array}{l}\text { Technological and } \\
\text { risk }\end{array}$ \\
\hline $\begin{array}{l}\text { National and international bank } \\
/ \text { Maritime and land transport } \\
\text { enterprise } \quad / \text { Technology } \\
\text { enterprise }\end{array}$ & $\begin{array}{l}\text { Service } \\
\text { providers }\end{array}$ & $\begin{array}{l}\text { "Provide safe and timely solutions for import and export } \\
\text { logistics chains" }\end{array}$ & $\begin{array}{l}\text { Technological and } \\
\text { risk }\end{array}$ \\
\hline $\begin{array}{l}\text { Chambers of customs, of } \\
\text { maritime port and trade in Chile }\end{array}$ & $\begin{array}{l}\text { Trade } \\
\text { associations }\end{array}$ & $\begin{array}{l}\text { "To coordinate and manage the trade union activity of our } \\
\text { partners" }\end{array}$ & Risk \\
\hline $\begin{array}{l}\text { Trade unions of the actors of the } \\
\text { export and import logistics } \\
\text { chains }\end{array}$ & Labor unions & $\begin{array}{l}\text { "To ensure safety and welfare to all workers affiliated to } \\
\text { the organization" }\end{array}$ & Risk \\
\hline
\end{tabular}

As shown in Fig. 2, when comparing the strategic phrases of the Port Community with the attributes of the strategic phrases from other stakeholders, it is noted that the PC falls short of strategies that are relevant to clients, strategic partners, service providers, trade associations and labor unions. In order to confront the complexity of the port, it is necessary for the Port Community to make strategic management decisions that include the strategic needs of the other players that make up the port system, especially because it receives various stimuli linked to risk and technology, although caused by external factors to it, they affect its appropriate strategic decision-making process.

\begin{tabular}{|c|c|c|}
\hline $\begin{array}{l}\text { Strategic phrases of Port } \\
\text { Community } \\
\text { "Ensure the provision of port } \\
\text { services to the logistics chain } \\
\text { and the customer, within a } \\
\text { framework of permanent } \\
\text { technological innovation that } \\
\text { provides high levels of quality } \\
\text { of service" }\end{array}$ & $\begin{array}{l}\text { Port Community } \\
\text { Clients } \\
\text { Strategic partners } \\
\text { Service providers } \\
\text { Trade associations } \\
\text { Labor unions }\end{array}$ & $\begin{array}{l}\text { Attribute of strategic phrases of Port } \\
\text { System: } \\
\text { 1. Technological innovntion } \\
\text { 2. Multimodal logistic connectivity } \\
\text { 3. Coordination of logistics chain } \\
\text { 4. Transport of physical goods } \\
\text { 5. Reliability of linancial services } \\
\text { 6. Link with trade orgailitalion } \\
\text { 7. Commercial coordination with national and } \\
\text { foreign clients } \\
\text { 8. Transportation coordination by land and sea }\end{array}$ \\
\hline
\end{tabular}

Fig. 2. Phrases and strategic attributes of port system, in the technological and risk context 
If we compare the gaps between the strategic phrases of the Port Community and the strategic attributes required by the Port System, it is noted that the PC sees itself as a service provider of the logistics chain. Hence, the Port Community meets the attributes required through other actors, and those attributes should be included in its strategic phrases on aspects related to risk, such as: the connectivity of multimodal logistics, coordination of actions between stakeholders, and reliability fostered by good practices.

It is also observed that there are risk strategic attributes, generated by importers and exporters who demand fast and reliable solutions, which involve security and coordination of port actors in the execution of operational activities. Moreover, the technological strategic attributes from some private actors are in accord with the Port Community needs concerning technological innovation in multimodal logistic connectivity. The results of this analysis were confirmed with experts' opinions in an interview with two senior executives from the Port Community, the experts selected the strategic attributes that are relevant to the PC.

Consequently, for the PC to make efficient and effective strategic decisions, it is necessary that its mission includes all the strategic attributes required by the port system, the interests of all actors should be integrated so that the Port Community could play its core business role, which would increase the degree of synergy between the actors. By complementing the strategic phrases of the PC with the strategic attributes of the port system, it is possible to obtain a single mission:

"Coordinate the multimodal port logistics chain by ensuring a comprehensive port service provision for customers, within a framework of permanent technological innovation with high levels of quality of service". It is necessary to emphasize that this new mission would place the Port Community in a position of leadership with respect to the actors of the logistics chain.

The relevant strategic objectives or alternatives are defined and selected according to the opinion of two port experts from the Ministry of Transport and Telecommunications belonging to the State of Chile, it is worth mentioning that this organization is consulted because ports are publicly owned and are granted under concession to private businesses. The experts say that the most relevant strategic alternatives that have to be complied, in the technological and risk context, are related to: management of information technology, control of port security, good practices and investment in technology and innovation.

\section{Table 2}

Nodes or strategic/operational indicators, in the technological and risk context

\begin{tabular}{|c|c|}
\hline $\begin{array}{ll}\begin{array}{l}\text { Strategy } \\
\text { (clusters) }\end{array} & \text { attributes } \\
\end{array}$ & Indicators (nodes) \\
\hline $\begin{array}{l}\text { Technological } \\
\text { innovation }(\mathrm{T})\end{array}$ & $\begin{array}{l}\text { T1: Amount of continuous education programs linked with technology. } \\
\text { T2: Percentage of resources aimed at innovation by the Port Authority. } \\
\text { T3: Rate of Integral technology projects to automate transaction processes among the actors of } \\
\text { the logistics chain. } \\
\text { T4: Number of technological investments for multimodal logistics and connectivity. }\end{array}$ \\
\hline $\begin{array}{l}\text { Coordination } \\
\text { actions }(\mathrm{O})\end{array}$ & $\begin{array}{l}\text { O1: Total permits for using port area. } \\
\text { O2: Rate of access to restricted zones controlled by the Port Community. } \\
\text { O3: Number of actions for risk prevention in cargo transportation by sea and land. } \\
\text { O4: Total of contracts used in port security. }\end{array}$ \\
\hline Compliance (C) & $\begin{array}{l}\text { C1: Number of fulfilled compromises under ethical behavior in port activities. } \\
\text { C2: Number of penalties for non-compliance with quality standards agreed by the Port Authority. } \\
\text { C3: Approved certifications rate. } \\
\text { C4: Labour accident index. } \\
\text { C5: Rate of prompt online processed documentation. }\end{array}$ \\
\hline $\begin{array}{l}\text { Influence on other } \\
\text { actors (I) }\end{array}$ & $\begin{array}{l}\text { I1: Number of documentary controls in the port area. } \\
\text { I2: Rate of Labour union proposals. } \\
\text { I3: Percentage of information transferred from terminals to the Port Authority. }\end{array}$ \\
\hline
\end{tabular}


Furthermore, each strategic attribute has to be controlled and measured with strategic/operational indicators that represent the following nodes: definition of standards, guide of good practices for port logistic communities, interoperable maritime single window design for export and import logistics chains, design of integrated electronic platforms for the Port Community to facilitate port operations. In Table 2, the nodes are designed for each cluster.

The results of this analysis were confirmed with the experts' opinion in interview with two senior executives from the Port Community.

\subsection{Design of the PORTGD model for the Port Community}

Fig. 3 shows how the application of the ANP model is related to data, information and explicit knowledge relevant to the decision-making by managers.

In order to design a generic conceptual model for a port (PORTGD) in the technological and risk context, the conceptual process of the multiple attribute group decision-making method (MAGDM) is used (Kabak \& Ervural, 2017). PORTGD is composed of stages of structuring and evaluation in which the clusters, alternatives and nodes detailed above are identified, as well as a port expert from the Port Community that is linked to the decisions of Strategic Management. The expert delivers his individual preferences, which are registered in the Superdecision software that applies the ANP (Analytical Network Process); the ANP model allows the comparison within clusters of elements (inner dependence) and among clusters (outer dependence) (Creative Decision Foundation, 2016; Saaty, 2001).

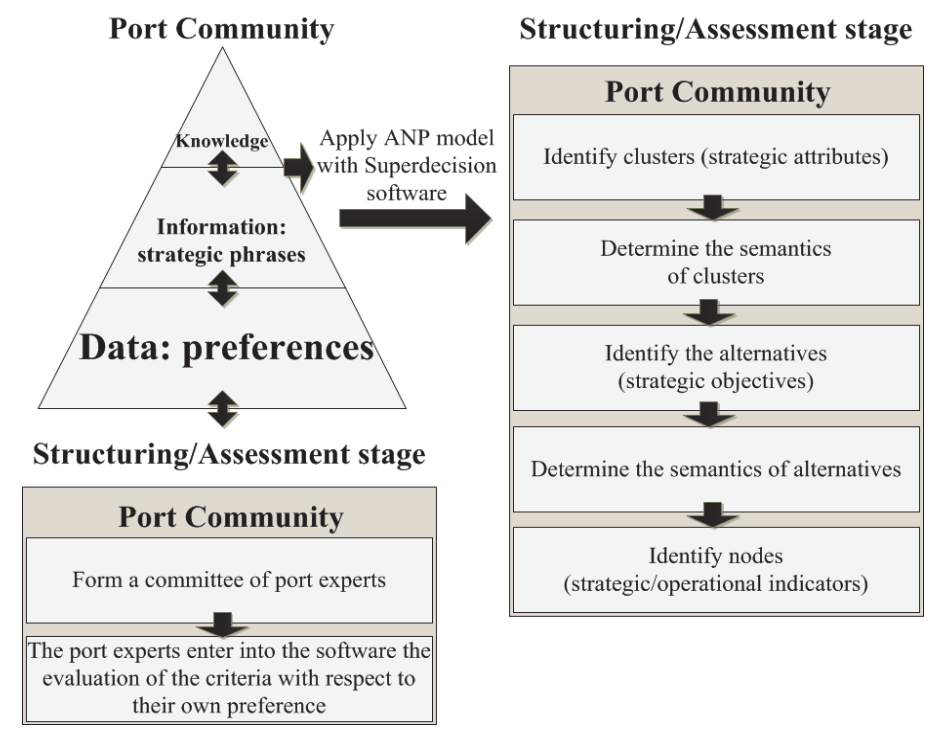

Fig. 3. Conceptual PORTGD model in the technological and risk context. Based (Kannan et al., 2014)

Fig. 4 shows an ANP conceptual model that will be applied in the PC, which is based on Table 2, in the strategic alternatives previously found and in the structuring / construction stage of the PORTGD model. 


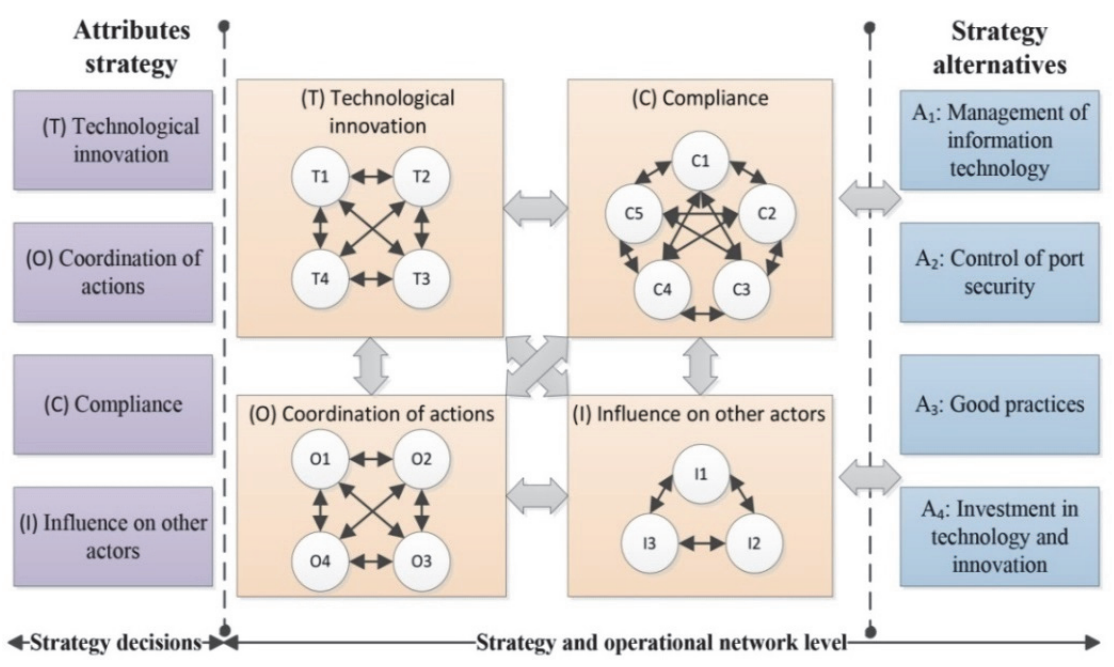

Fig. 4. The conceptual ANP model for Port Community

This analysis was validated by interviewing two experts from the Port Community.

\section{Results}

\subsection{Application of the ANP model}

As shown in Fig. 3 in the structuring / construction stage of the PORTDG model, the preferences of the port expert are entered in the software Super decision, the pairwise comparisons are carried out according to the fundamental scale of values; with values from 1 to 9 , where if the expert chooses 1 , it shows equal importance between two elements that can be the ordered pairs that are formed by the combination of alternatives, clusters or nodes. If the expert chooses a higher number, there is greater influence from one element over another; in particular 9 represents an extreme importance of one element over another (Saaty \& Vargas, 2012). The judgment expert values entered into the software generate the positive matrix $A$, the eigenvalues are formulated to obtain the priority vector with the eigenvector $w$ (or weights) and $\lambda_{\max }$ is its maximum eigenvalue (Ocampo \& Seva, 2016):

$$
A w=\lambda_{\max } w
$$

It is verified that the judgment given by the port expert is consistent through the consistency index (CI), which is considered that the closer to zero the smaller the inconsistency (Saaty \& Vargas, 2012). The consistency ratio (CR) is calculated (Alonso \& Lamata, 2006), as shown in:

$$
\begin{aligned}
& C I=\frac{\lambda_{\max }-n}{n-1}, \\
& R I=\frac{\bar{\lambda}_{\max }-n}{n-1}, \\
& C R=\frac{C I}{R I}<0.1 .
\end{aligned}
$$

With $n=$ number of elements, $R I=$ random index.

According to Saaty \& Vargas (2012) eigenvectors are calculated and the supermatrix $W$ is obtained, as shown in:

$$
\left(W_{i 1}^{j t}, W_{i 2}^{j t}, \ldots, W_{i t}^{j t}\right)^{T}
$$




$$
W=\left[\begin{array}{cccc}
W \_11 & W \_12 & \cdots & W_{-} 1 m \\
W \_21 & W \_22 & \cdots & W_{-} 2 m \\
\vdots & \vdots & \ddots & \vdots \\
W \_m 1 & W \_m 2 & \cdots & W \_m m
\end{array}\right]
$$

In Fig. 5 appear the partial results obtained with the Super Decision software, it is noted in the Super matrix the degree of influence among alternatives and nodes of the model ANP model investigated. It is observed that the columns of each vector of the supermatrix represent the importance that all the elements have for each element of a cluster (Saaty \& Vargas, 2012).

\begin{tabular}{|c|c|c|c|c|c|c|c|c|c|c|c|c|c|c|c|c|}
\hline & C1 & C2 & C3 & C4 & C5 & I1 & 12 & 13 & 01 & $\mathrm{O} 2$ & $\mathrm{O} 3$ & $\mathrm{O} 4$ & $\mathrm{~T} 1$ & $\mathrm{~T} 2$ & T3 & T4 \\
\hline $\mathrm{C} 1$ & b.339 [ & 0.102 & 0.297 & $0.190 \rrbracket$ & 0.075 & 0.369 & 0.162 & 0.195 & 0.259 & 0.123 ] & 0.086 & $0.184]$ & 0.097 & 0.130 & $0.123]$ & 0.105 \\
\hline $\mathrm{C} 2$ & $0.086 \square$ & 0.124 & 0.160 & 0.193 & 0.212 & 0.133 & ] 0.308 | & 0.061 & 0.166 & 0.370 & 0.194 & 0.379 & 0.058 & 0.416 & 0.108 & 0.083 \\
\hline $\mathrm{C} 3$ & 0.299 & 0.159 & 0.201 & 0.407 & 0.242 & 0.077 】 & $0.080 \square$ & 0.094 & 0.235 & 0.204 & 0.485 & 0.143 & 0.262 & 0.122 & 0.086 & 0.175 \\
\hline $\mathrm{C4}$ & 0.212 & 0.545 & 0.256 & 0.141 & 0.076 & 0.108 & $0.411]$ & 0.099 & 0.252 & 0.229 & 0.205 & $0.259 \mid$ & 0.036 & 0.061 & $0.061]$ & 0.072 \\
\hline C5 & $0.064 \rrbracket$ & $0.071]$ & $0.087 \rrbracket$ & 0.068 & 0.395 & $|0.312|$ & 0.038 & 0.551 & 0.089 & 0.074 & 0.030 & 0.036 & 0.547 & 0.270 & 0.622 & 0.565 \\
\hline 11 & $0.155 \square$ & 0.121 & $0.149 \square$ & 0.100 & 0.255 & 0.578 & 0.260 & 0.364 & 0.800 & 0.694 & 0.208 & 0.286 & 0.232 & 0.345 & 0.373 & 0.376 \\
\hline 12 & 0.710 & 0.764 & 0.376 & 0.800 & 0.101 』 & 0.057 & 0.413 & 0.057 & 0.100 & 0.132 & 0.661 & 0.571 & 0.584 & 0.109 & 0.061 & 0.149 \\
\hline 13 & 0.135 & 0.115 & 0.474 & 0.100 & 0.643 & 0.364 & 0.327 & 0.578 & 0.100 & $0.174 \square$ & 0.131 & 0.143 & 0.184 & 0.547 & 0.566 & 0.474 \\
\hline 01 & 0.347 & 0.195 & 0.138 & 0.250 & 0.244 & 0.409 & 0.108 & 0.594 & 0.393 & 0.403 [ & 0.089 & 0.148 & 0.299 [ & 0.141 & 0.252 & 0.086 \\
\hline $\mathrm{O} 2$ & 0.246 & $0.115]$ & $0.110^{-}$ & 0.250 & 0.491 & $0.371 \square$ & 0.118 & 0.114 & 0.459 & 0.443[ & 0.104 & 0.163 & 0.209 & 0.330 & $0.374 \square$ & 0.121 \\
\hline 03 & 0.204 & 0.368 & 0.366 & 0.250 ॥ & 0.056 & 0.152 & 0.532 & 0.152 ] & 0.084 & 0.075 & 0.310 & 0.363 & 0.253 & 0.388 & 0.098 & 0,437 \\
\hline 04 & 0.204 & 0.322 & 0.386 & 0.250 & 0.209 ] & 0.068 & 0.241 & $0.140 \rrbracket$ & 0.064 & 0.079 & 0.497 & 0.326 & 0.239 & 0.141 & 0.276 & 0.357 \\
\hline $\mathrm{T} 1$ & 0.233 & 0.168 & 0.587 & 0.250 ] & 0.092 & 0.111 & 0.586 & $0.047 \|$ & 0.061 & 0.116 & 0.506 & 0.167 【 & $0.062 \|$ & 0.043 & 0.094 & 0.141 \\
\hline $\mathrm{T} 2$ & | $0.278 \mid$ & 0.198 & 0.096 & 0.250 & 0.137 & 0.288 & 0.161 & 0.411 & 0.317 & 0.131 & 0.153[ & 0.104 & 0.453 & 0.392 & 0.343 & 0.165 \\
\hline T3 & 0.124 & 0.395 & 0.222 & 0.250 & 0.631 & $0.371]$ & 0.099 & 0.371 & 0.417 & 0.099 & 0.126 & 0.130 & 0.165 & 0.153 & $0.141]$ & 0.096 \\
\hline T4 & 0.366 & 0.239 & 0.096 & 0.250 & 0.140 & 0.230 & 0.154 & 0.171 & 0.205 & 0.654 & 0.215 & 0.599 & 0.320 & 0.412 & 0.422 & 0.598 \\
\hline
\end{tabular}

Fig. 5. Unweighted Super Matrix of the Port Community.

When analyzing the ordered pairs of each column of nodes, we can see that the highest influences are related to: commitments for ethical behavior in port activities (C1) / union proposals (I2), with sanctions for non-compliance with the quality standards agreed by the Port Authority (C2) / the proposals of the unions (I2) and with the total number of permits (O1) / documentary controls used in the port area (I1). In relation to the lowest influences, they have links with: risk prevention actions by land and sea transport (O3) / speed of on-line processing of documentation (C5), contracts used in port security (O4)/ speed of on-line processing of documentation (C5) and continuing education programs in technology (T1) / occupational accidents (C4). This analysis was validated by interviewing two experts from the Port Community.

Each sub-matrix $\mathrm{W}_{\mathrm{ij}}$ in the supermatrix column is normalized. By multiplying the supermatrix $\mathrm{W}$ by the weighted matrix $A\left(a_{i j}\right)$ we obtain the weighted supermatrix shown in Fig. 6, for the alternatives and nodes that were described in Fig. 4.

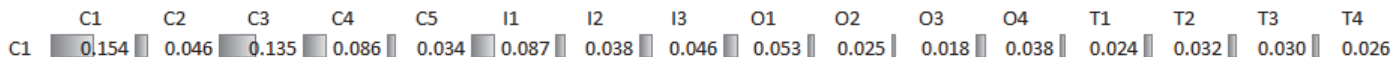
$\mathrm{C} 2 \square 0.039 \square 0.056 \square 0.072 \square 0.088 \square 0.096 \rrbracket 0.031 \square 0.072 \rrbracket \quad 0.014 \rrbracket 0.034 \square 0.076 \square 0.040 \square 0.077 \rrbracket 0.014 \square 0.101 \rrbracket 0.026 \rrbracket 0.020$

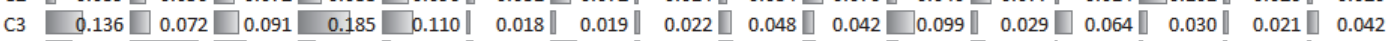

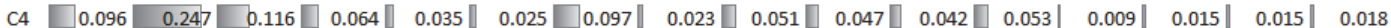

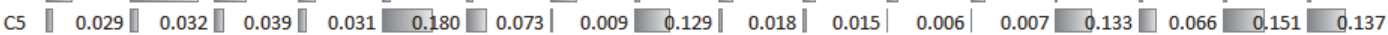

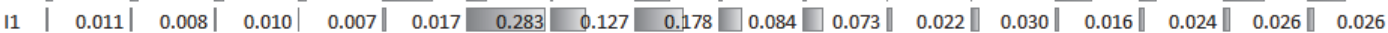

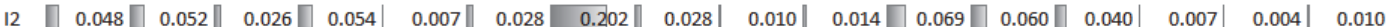

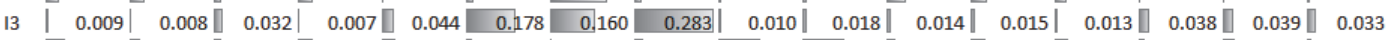

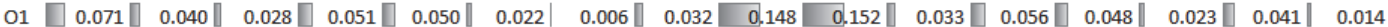
$\mathrm{O} 2 \square 0.050 \rrbracket 0.024 \rrbracket 0.022 \square 0.051 \square 0.100 \rrbracket \quad 0.020|0.006| 0.006 \quad 0.173 \quad 0.167 \square 0.039 \square 0.061 \rrbracket 0.034 \square 0.053 \square 0.060 \rrbracket 0.020$

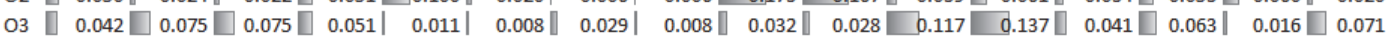

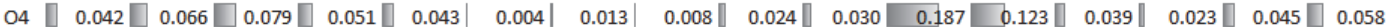

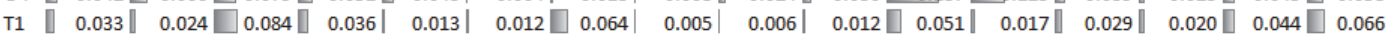

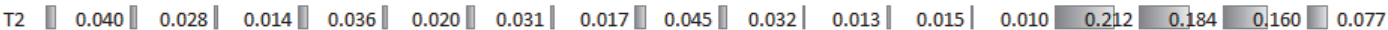

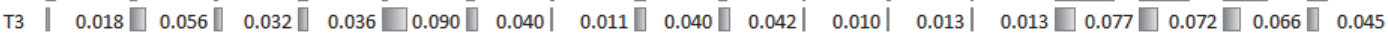

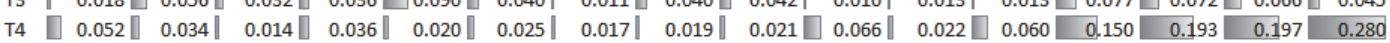

Fig. 6. Weighted Super Matrix of the Port Community. 
Finally, the limiting priorities of all elements of the stochastic matrix are calculated and the final priorities of the elements are indicated in Fig. 7.

It should be noted that the nodes most valued by the experts refer to the investment in technological innovation that improves the connectivity of the export and import logistics chains, the transfer of information among the actors and the documentary control of the activities carried out in the external and internal port terminals. There is also greater appreciation of technology and risk strategic decisions because they foster good practices and ensure port security control.

\subsection{Cause-effect analysis}

In order to determine cause-effect influences between two nodes, the Decision Making Trial and Evaluation Laboratory Model (DEMATEL) is used to determine cause-effect relationships between two nodes of the ANP model (Lee et al., 2011; Yang \& Tzeng, 2008). DEMATEL is applied to the weighted weight matrix shown in Fig. 6: the elements of the matrix are normalized, the matrix of relations $\mathrm{S}$ is calculated, its columns and rows are summed and the criteria of the DEMATEL model are applied (Durán et al., 2018; Yang \& Tzeng, 2011).

When comparing the results of Fig. 7 and Fig. 8, it can be seen that the nodes that cause relations correspond to the decisions that the Port Community has to make to control on a daily basis the operational activities of the land transportation within the Terminals, including documentary, information control, ethical behavior and quality standards agreed by The Port Authority. Likewise, the investment in technology to improve multimodal logistics and connectivity is considered to be the cause, which is considered important for the public property medium-sized Chilean port, as it is part of the development strategies for Chile by the year 2030 .

With respect to the effects shown in Fig. 8, they are related to technological education programs, automation process and technological innovation. In relation to trade unions, they are also relevant because they exert great power over port activities, especially because they can go on strike, which prevents the commercialization of goods with other countries, affecting the markets.

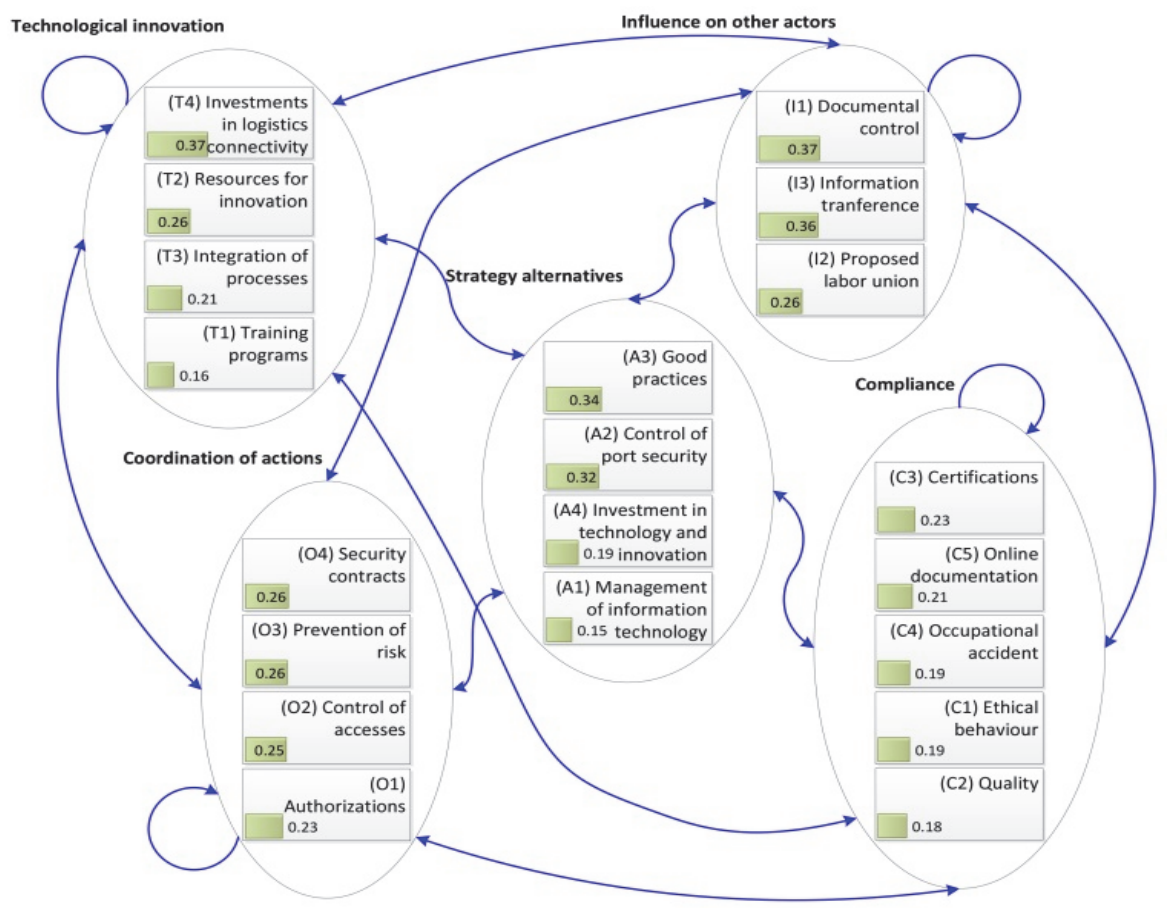

Fig. 7. ANP model of the Port Community 


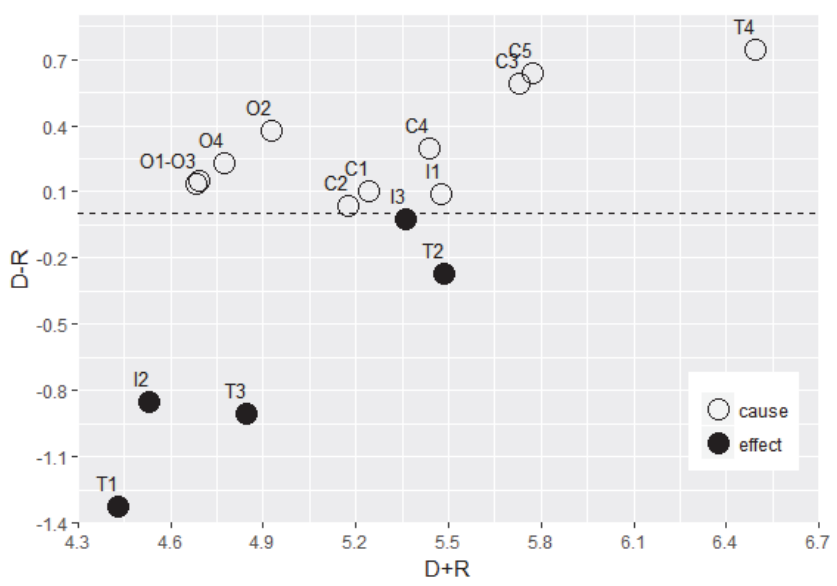

Fig. 8. Cause and effect Diagram, based in Unweighted Super Matrix of the Port Community

It can be said that the causes are linked to the short-term management decisions that are necessary for the daily operation of a port and that the effects are more related to the mid- and long-term planning decisions that promote technological innovation.

\section{Discussion}

\subsection{Sensitivity analysis}

A sensitivity analyzes is shown in Fig. 9, where different scenarios are generated by entering four values to the sensitization parameter $p$ in the Superdecision Software. This is done with the purpose of analyzing the weight each expert gives to the Port Community through to the different nodes of the ANP model. Note that if $p=0.5$ we have the original values of Fig. 7 and if $p>0.5$ means that the importance of the node increases (Saaty \& Vargas, 2012).

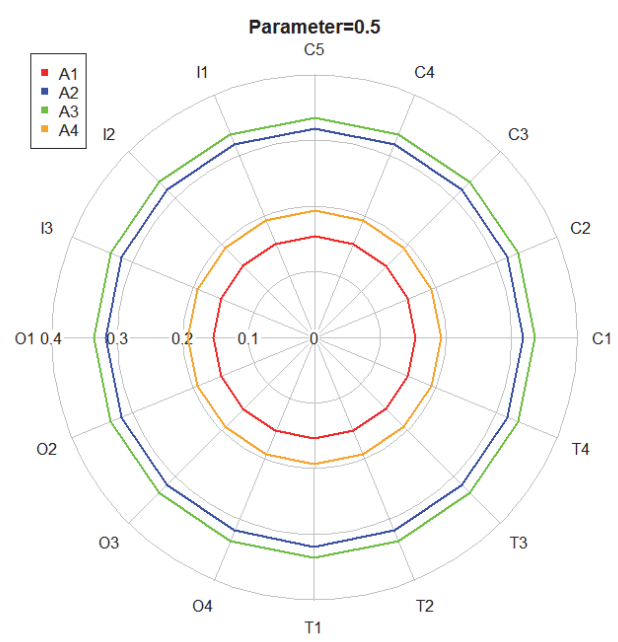

(a) Parameter 0.5.

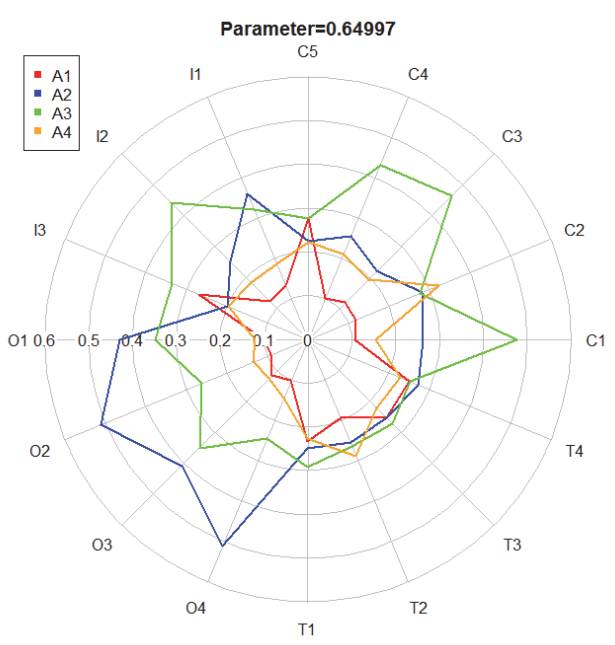

(b) Parameter 0.64997. 


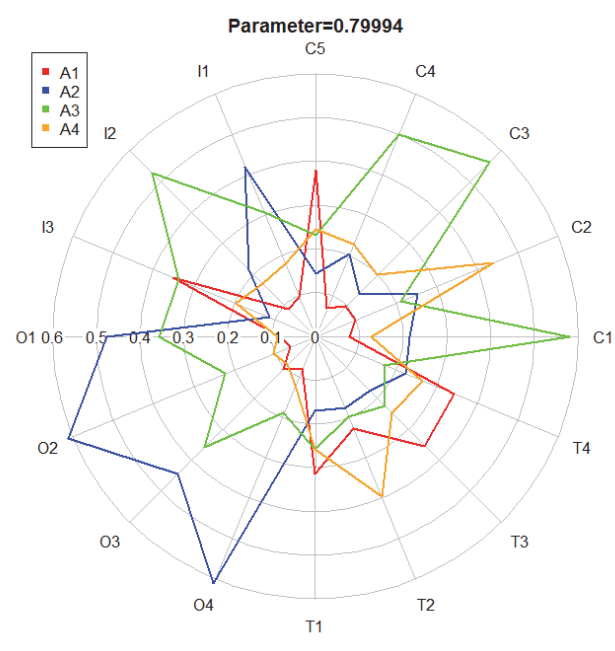

(c) Parameter 0.79994.

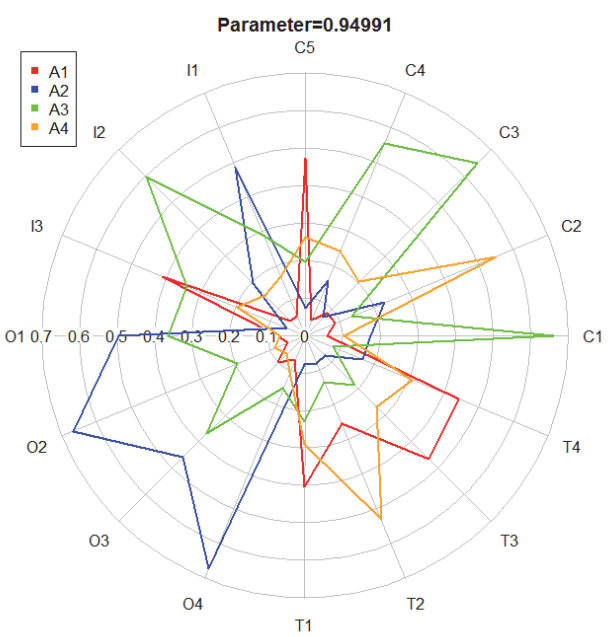

(d) Parameter 0.94991.

Fig. 9. Sensitivity analysis for the ANP port model.

In relation to the ANP model for the Port Community, it is observed that the preferences of the nodes vary for the alternatives. In particular, there is a greater increase in node preference for alternatives in existing relationships: between ethical conduct commitments in port activities / good practices and port security contracts / access controls to restricted areas.

\subsection{Implications of PORTGD model}

A decision model has been designed for the actors involved in the port core business, the research includes all private actors that have a synergistic level of strategic relationship with the Port Manager and the internal / outsourced terminals, in the technological and risk aspects. The opinion of port experts has been used to make a diagnosis and the design of a decision-making model, which is not only based on the strategies defined by the Port Community but also represents the needs and expression of the entire port system.

By analyzing the decisions found in the strategic phrases of their missions, Figure 2 shows that actors of the port system express in their statements more attributes associated with risk than technology. As can be expected, port security becomes crucial since it affects action coordination of all actors participating in the import/export logistics chain, trade associations and social groups. With regard to alternatives, at the arrival and delivery of products in containers, to and from other countries, the port must permanently control all of its activities which represent a source of risk; for this reason, port experts consider good practices and security control as highly relevant. It is observed that according to port expert answers, logistic connectivity is important for the Port Community, which is in accord with the Strategic Plan of the country because it states the need of investing in new roads for land transportation of cargo. With reference to documental control and information transference, there is a need of integrated and collaborative platforms that facilitate information management among all actors, making the Port Community Control Management more efficient and effective.

Because the port is publicly owned, it is important to say that the ANP model agrees with the concerns of the Ministry of Transport and Telecommunications (MTT), which by law has to coordinate and regulate port actions. The MTT has determined as strategic goals the definition of interoperability standards and good practices, and the integration / coordination of information technologies among the port actors that integrate the export and import logistics chain and the public actors that exercise the role of inspectors of the physical goods that enter and leave the port. In relation to the State's concerns about ports, they include data security, the elimination of barriers to interoperability, and the scalability of digital services and transactions. 


\section{Conclusions}

Furthermore, with the results found in the research it is possible to conclude that the Port Community has an important need to invest in technological innovation; consequently, it has to request the State more economic resources to generate new technological projects. Another important aspect to consider is that innovation requires a cultural change, so the Port Manager and the internal / outsourced Terminals have to adapt to new information and communication processes that can affect the Port Community's synergy with the Companies providing logistics services, social groups and trade associations. Thus, by incorporating more technological innovation it would be closer to meeting the strategic solutions that our country needs for the year 2030, in which it is proposed to develop technological solutions applied to the port productive processes that add value to each stage of the process and that help to cope with the demanding standards linked with the environment and port security. Chile could reduce gaps with other world-class ports and could become a strategic platform in Latin America.

The main limitation of the present study was the lack of research that exists in ANP management models in Chilean ports and other places around the world. It should be noted that the study only makes a diagnosis to identify the important aspects that need to be improved in decision making by port managers and shows the synergy relationships that can be generated in Management Control.

It is emphasized that more research on the subject is required, especially, to investigate in more detail each element of the ANP model.

\section{Acknowledgments}

This work was supported by DICYT USACH Project. Universidad de Santiago de Chile.

\section{References}

Alonso, J. A., \& Lamata, M. T. (2006). Consistency in the analytic hierarchy process: a new approach. International Journal of Uncertainty, Fuzziness and Knowledge-Based Systems, 14(4), 445-459. https://doi.org/10.1142/S0218488506004114.

Aydogdu, Y. V., \& Aksoy, S. (2015). A study on quantitative benefits of port community systems. Maritime Policy \& Management, 42(1), 1-10. https://doi.org/10.1080/03088839.2013.825053.

Cao, J., Chi, Y., \& Wu, X. (2010). The study of ANP-Based strategic decision model for green supply chain. In 2010 International Conference on Logistics Systems and Intelligent Management (ICLSIM) (pp. 64-68). IEEE. https://doi.org/10.1109/ICLSIM.2010.5461469.

Carlan, V., Sys, C., \& Vanelslander, T. (2016). How port community systems can contribute to port competitiveness: Developing a cost-benefit framework. Research in Transportation Business \& Management, 19, 51-64. https://doi.org/10.1016/j.rtbm.2016.03.009.

Creative Decision Foundation. (2016). SuperDecisions software. Retrieved from https://www.superdecisions.com/.

Do Carmo, M., Mendes, R., Frederico, G., Odorczyk, R. S., Cordova, F. M., \& Duran, C. A. (2016). Theoretical aspects of the information and knowledge engineering. In 2016 6th International Conference on Computers Communications and Control (ICCCC) (pp. 201-207). IEEE. https://doi.org/10.1109/ICCCC.2016.7496761.

Durán, C., \& Cordova, F. (2016). Conceptual Model to Identify Technological Synergic Relationships of Strategic Level in a Medium-sized Chilean Port. Procedia Computer Science, 91, 382-391. https://doi.org/10.1016/j.procs.2016.07.100.

Durán, C., \& Córdova, F. (2015). Synergy and Technology Gaps in Export Logistics Chains between a Chilean and a Spanish medium-sized Port. Procedia Computer Science, 55, 632-641. https://doi.org/10.1016/j.procs.2015.07.055.

Durán, C., Sepulveda, J., \& Carrasco, R. (2018). Determination of technological risk influences in a 
port system using DEMATEL. Decision Science Letters, 7(1), 1-12. https://doi.org/10.5267/j.dsl.2017.5.002.

Hao, S., \& Song, M. (2016). Technology-driven strategy and firm performance: Are strategic capabilities missing links? Journal of Business Research, 69(2), 751-759. https://doi.org/10.1016/j.jbusres.2015.07.043.

Hsu, C.-M. (2011). A hybrid procedure for stock price prediction by integrating self-organizing map and genetic programming. Expert Systems with Applications, 38(11), 14026-14036. https://doi.org/10.1016/j.eswa.2011.04.210.

Kabak, Ö., \& Ervural, B. (2017). Multiple attribute group decision making: A generic conceptual framework and a classification scheme. Knowledge-Based Systems, 123, 13-30. https://doi.org/10.1016/j.knosys.2017.02.011.

Kannan, D., Lopes de Sousa Jabbour, A. B., \& Chiappetta Jabbour, C. J. (2014). Selecting green suppliers based on GSCM practices: Using fuzzy TOPSIS applied to a Brazilian electronics company. European Journal of Operational Research, 233(2), 432-447. https://doi.org/10.1016/j.ejor.2013.07.023.

Keceli, Y. (2011). A proposed innovation strategy for Turkish port administration policy via information technology. Maritime Policy \& Management, 38(2), 151-167. https://doi.org/10.1080/03088839.2011.556676.

Lee, W.-S., Huang, A. Y., Chang, Y.-Y., \& Cheng, C.-M. (2011). Analysis of decision making factors for equity investment by DEMATEL and Analytic Network Process. Expert Systems with Applications, 38(7), 8375-8383. https://doi.org/10.1016/j.eswa.2011.01.027.

Montibeller, G., \& Belton, V. (2006). Causal maps and the evaluation of decision options-a review. Journal of the Operational Research Society, 57(7), 779-791.

Ocampo, L. A., \& Seva, R. R. (2016). Using analytic network process for evaluating mobile text entry methods. Applied Ergonomics, 52, 232-241. https://doi.org/10.1016/j.apergo.2015.07.022.

Saaty, T. L. (2001). Decision making with dependence and feedback: The analytic network process. Pittsburgh. RWS Publications, 7, 557-570.

Saaty, T. L., \& Vargas, L. G. (2012). The Seven Pillars of the Analytic Hierarchy Process. In Models, Methods, Concepts \& Applications of the Analytic Hierarchy Process (Vol. 175, pp. 23-40). Springer US. https://doi.org/10.1007/978-1-4614-3597-6_2.

Sandhya, S., \& Garg, R. (2016). Implementation of multi-criteria decision making approach for the team leader selection in IT sector. Journal of Project Management, 1(2), 67-75.

Van Oosterhout, M. P. A., Veenstra, A. W., Meijer, M. A. G., Popal, N., \& Van den Berg, J. (2007). Visibility platforms for enhancing supply chain security: a case study in the Port of Rotterdam. In Proceeding of the International Symposium on Maritime Safety, Security and Environmental Protection, Athens (pp. 20-21).

Wei, H. (2010). Cooperation and Competition of Interfirm Network Organizations: The Function of Synergies. In 2010 International Conference on E-Business and E-Government (pp. 2339-2342). IEEE. https://doi.org/10.1109/ICEE.2010.591.

Wu, W.-W., \& Lee, Y.-T. (2007). Selecting knowledge management strategies by using the analytic network process. Expert Systems with Applications, 32(3), 841-847. https://doi.org/10.1016/j.eswa.2006.01.029.

Yang, J. L., \& Tzeng, G.-H. (2011). An integrated MCDM technique combined with DEMATEL for a novel cluster-weighted with ANP method. Expert Systems with Applications, 38(3), 1417-1424. https://doi.org/10.1016/j.eswa.2010.07.048.

Yang, Y., Yang, S. L., \& Yang, J. (2013). A BSC-ANP model for evaluation of strategic fit of new product development projects. In 2013 25th Chinese Control and Decision Conference (CCDC) (pp. 1643-1647). IEEE. https://doi.org/10.1109/CCDC.2013.6561194.

Zhong, M., Wu, Y., \& Luan, W. (2011). Model of synergy degree between port logistics and urban economy. Journal of Dalian Maritime University, 37(1), 80-82. 


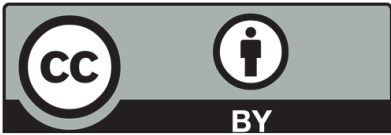

(C) 2018 by the authors; licensee Growing Science, Canada. This is an open access article distributed under the terms and conditions of the Creative Commons Attribution (CC-BY) license (http://creativecommons.org/licenses/by/4.0/). 